\title{
THE TEST OF AMERICAN CULTURE
}

\section{Kenji Kitao}

About one million Japanese people visit the United States each year. More Japanese encounter more American people and culture on a daily basis than in the past. As such encounters increase, more misunderstandings and miscommunications occur. These arise not only because of language barriers but also because of cultural barriers.

In the English teaching profession in Japan. American culture has been emphasized recently, because of the stress on communication. However, my former studies, reviewing high school English textbooks and questionnaires completed by 63 Japanese students in the United States show that culture is taught neither extensively nor well. They do not learn culture well at any level and this contributed to their cultural shock and poor intercultural communication they experienced in the United States.

There are not many studies on teaching culture; I could not find any books or articles on what to teach about American culture, nor how to teach it. There are no standardized examinations to measure the knowledge of American culture in Japan.

The purpose of this study is to measure which items of American culture Japanese students know and to what degree they understand each item. So with the cooperation of American informants and Japanese students in the United States, I developed an objective culture examination, the Test of American Culture using books on American culture.

In this study, I define 'culture' as; the knowledge and behavior that a people in the same language community have learned and share among themselves.

\section{Construction of the Test of American Culture}

The test is a written one with all questions in English. Such a format is chosen because: (1) many people can be examined with a paper test, (2) language and culture should not be separated, (3) some questions could not be given in Japanese and (4) I was planning to test some American students as a control group.

The test had four pages of questions and one separate answer sheet. All the questions are multiple choice with four options from which the students choose the best answer. Thus, this test gives an objective way to check students' knowledge of particular items and can measure the degree of understanding of each item.

The test concerns 49 different areas of American culture. One area "Measurement" is included twice to cover weight, length, and amount of liquid. These fifty areas are shown in Table I.

The 50 areas cover both Culture with a big C, such as literature, music, history, and industry; and culture with a small $c$, such as nicknames, food, and meals. They include some practical items necessary and useful for foreign visitors (the telephone, postage, 
measurements, money, etc.) as well as a number of aspects of covert culture (time, space, etc.)

For each item, two questions were composed. Two parallel tests,

TABLE 1

AREAS IN THE TEST OF AMERICAN CULTURE

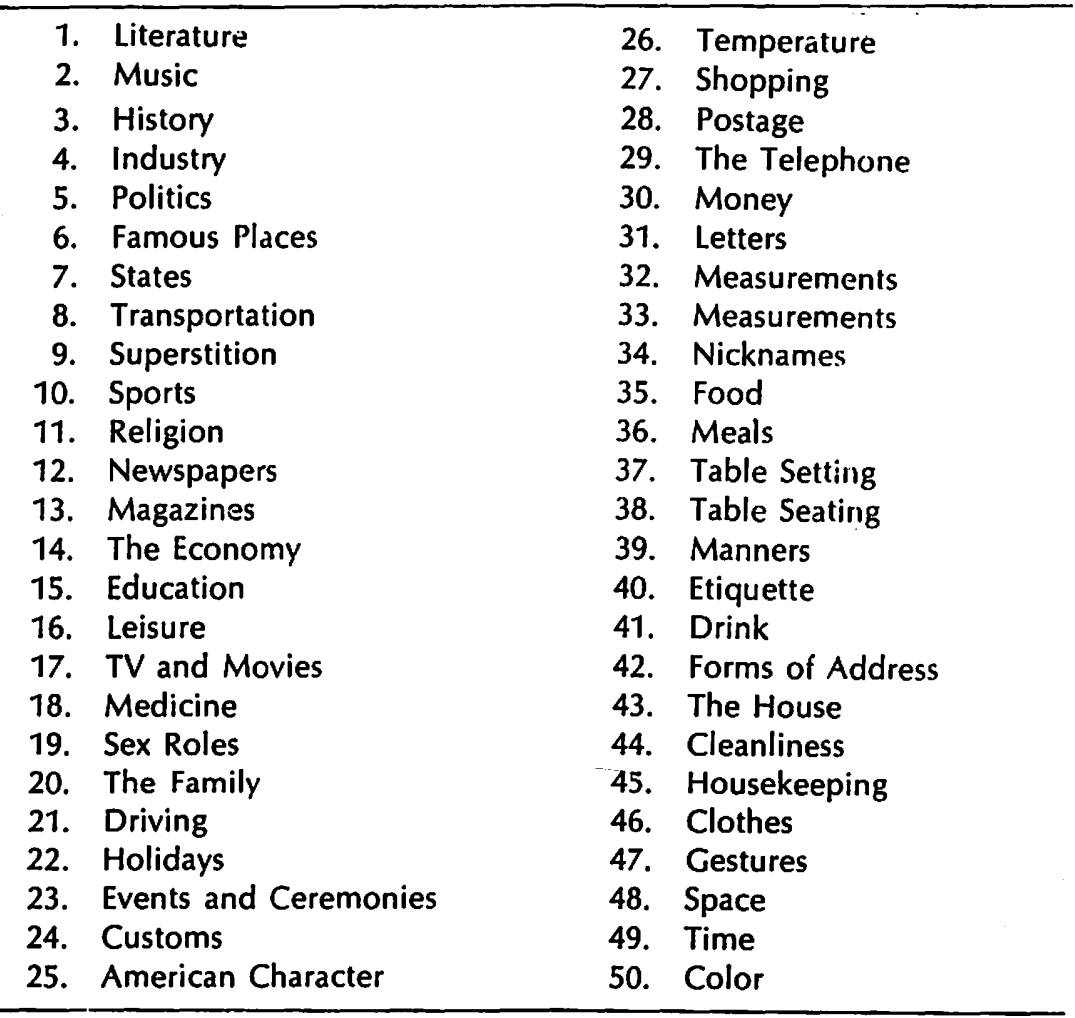

numbered 1-50 and 51-100, were created. In each part, the questions were in the order shown in Table I. In 1-50, the subject must select the word or phrase most closely related to the given keyword or prases. In 51-100, the student, given a sentence with a blank, must choose the best word or phrase from a list of four.

Examples:

23. Fourth of July: (a) minister (b) turkey and dressing (c) fireworks

(d) colored eggs

76. Water begins to freeze at-F. (a) 0 (b) 10 (c) 21 (d) 32 


\section{Administration of the Test of American Culture}

The test was administered to 20 American students at the University of Kansas (Group 1) as a control group, and 200 Japanese students as an experimental group. The experimental group included six kinds of students: 40 Japanese students at the University of Kansas (II), 18 high school students preparing to participate in exchange student programs in the United States (III), 23 sophomores at Kagawa Nutrition College (IV), 51 night-class students at Kagawa Nutrition Junior College (V), 26 sophomore English majors at Joshi Seigakuin Junior College (VI) and 42 freshmen elementary education majors at Joshi Seigakuin Junior College (VII).

K.U. Japanese students (II) had learned much about American culture during their stay in the United States. The high school students (III) had been selected for exchange student programs and were preparing to go to the United States in the summer of 1976. They had received some orientation into American culture. Those students in Group IV were superior students whose grades in senior high school had been high. The night school students in Group V had very low English proficency. As English majors. Group VI showed high interest in this test. Group VII demonstrated some difficulty in English. In general, the non-English majors in Japan had some trouble with English.

Students in Groups I and II took the test individually in March, 1976, at the University of Kansas. The Americans spent between 9 and 25 minutes, and the Japanese, between 18 and 19 minutes to complete the test. All students in Group III took the test on April 3 in Kyato together, and finished it within sixty minutes. Groups IV, V, VI and VII took the test in their classes and spent $60,70,75$ and 80 minutes respectively. One student in Group IV, 10 in Group V, 5 in Group VII lacked more than ten questions of finishing and their responses were climinated from the following anaylsis and evaluations.

\section{Analysis and Evaluations of the Results of the Test of American Culture \\ Differences of Groups}

The frequency distributions of the total scores of the individual students in each group are shown in Table 2. As I predicted, the Americans (I) obtained the highest scores, the K.U. Japanese students (II), the second highest, and the high school students (III), the third highest. Among the Japanese college students, English majors (VI) scored the highest, and the night students (V) the lowest.

The scores of 18 of the 20 Americans fell between 80 and 90 percent. Their mean score was 85.25, and the standard deviation was 3.90 . Even though not all of them scored as high as was expected, the American scores were homogeneous.

I administered a multiple range test with the Scheffe procedure at the 0.05 level. This test determined that Group II was also significantly different from any other group. However, this test did not distinguish any other groups significantly from the viewpoint of culture. Therefore, this test determined three significantly different 
groups: American students (I), K.U. Japanese students (II), and other Japanese students.

This means that Americans knew American culture better than any Japanese students and the the K.U. Japanese students knew it much better than the Japanese students in Japan.

Since high school students had much different backgrounds from other Japanese students in Japan, Group III was eliminated and other

\section{TABLE 2}

FREQUTNCY DISTRIBUTIONS OF THE TOTAL SCORES OF INDIVIDUAL STUDENTS IN THE TEST OF AMERICAN CULTURE

\begin{tabular}{|c|c|c|c|c|c|c|c|}
\hline \multirow[b]{2}{*}{ Scores } & \multicolumn{6}{|c|}{ Groups } & \multirow[b]{2}{*}{ VII } \\
\hline & 1 & 11 & III & IV & V & V & \\
\hline \multicolumn{8}{|l|}{$96-100$} \\
\hline $91-95$ & 1 & & & & & & \\
\hline 86- 90 & 10 & & & & & & \\
\hline $81-85$ & 8 & 1 & & & & & \\
\hline $76-80$ & & 4 & & & & & \\
\hline $71-75$ & 1 & 6 & & & & & \\
\hline $66-70$ & & 6 & & & & & \\
\hline $61-65$ & & 12 & & & & & \\
\hline $56-60$ & & 3 & 2 & & & & \\
\hline $51-55$ & & 5 & 3 & & & 3 & \\
\hline $46 \cdot 50$ & & 1 & 6 & 3 & & 7 & \\
\hline $41-45$ & & 2 & 2 & 7 & 1 & 8 & 13 \\
\hline $36-40$ & & & 1 & 6 & 5 & 2 & 5 \\
\hline $31-35$ & & & 3 & 3 & 14 & 5 & 13 \\
\hline $26-30$ & & & & 3 & 11 & 1 & 4 \\
\hline $21-25$ & & & 1 & . & 6 & & 1 \\
\hline 16- 20 & & & & & 3 & & 1 \\
\hline $11-15$ & & & & & & & \\
\hline $6-10$ & & & & & 1 & & \\
\hline Norm & 20 & 40 & 18 & 22 & 41 & 26 & 37 \\
\hline Mean & 85.25 & 63.93 & 44.89 & 39.14 & 29.20 & 42.46 & 36.0 \\
\hline S. D. & 3.90 & 9.74 & 9.03 & 6.21 & 6.30 & 6.70 & $6.2 \pi$ \\
\hline
\end{tabular}

four groups were merged into one, the Japanese-college students (Group VIII). These only three significantly different groups were used for further analysis and evaluations.

Analysis of Items Comparisons between the Americans and the Japanese Students

The percentage of correct answers to each question and each item was computed with a computer. The frequency distribution of the 
items by percentage of students answering correctly and the subjects of these items listed in the order of difficulty for each group are shown in Table 3.

TABLE 3

SUBIECTS OF ITEMS ARRANGED IN ORDER OF PERCENTAGE

OF CORRECT ANSWERS FOR EACH GROUP

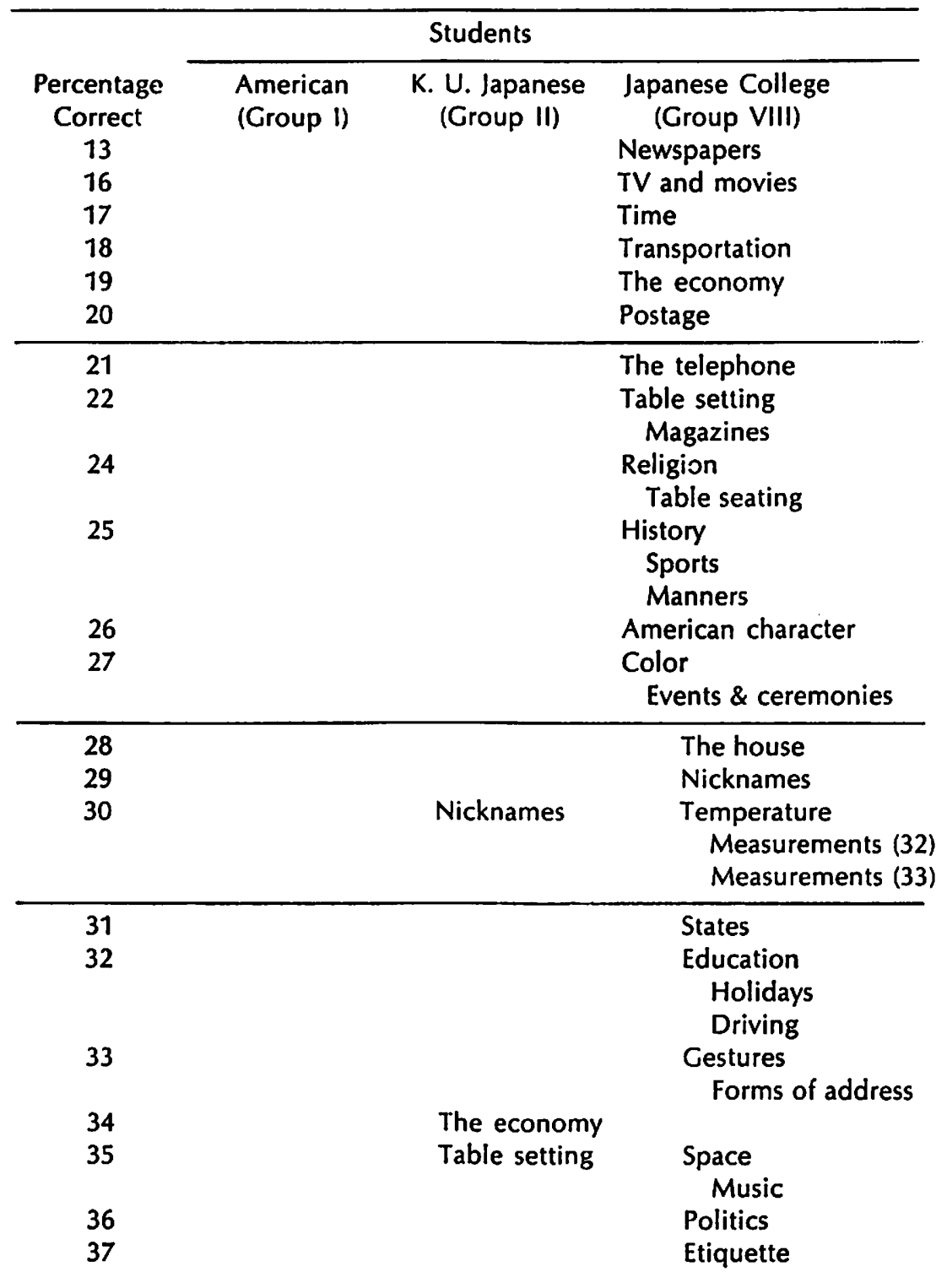


TABLE 3 (Continued)

\begin{tabular}{|c|c|c|c|}
\hline \multirow[b]{2}{*}{$\begin{array}{l}\text { Percentage } \\
\text { Correct } \\
38 \\
39 \\
40\end{array}$} & \multicolumn{2}{|c|}{ Students } & \multirow[b]{2}{*}{$\begin{array}{l}\text { Japanese College } \\
\quad \text { (Group VIII) } \\
\text { Housekeeping } \\
\text { Clothes }\end{array}$} \\
\hline & $\begin{array}{l}\text { American } \\
\text { (Group I) }\end{array}$ & $\begin{array}{c}\text { K.U. Japanese } \\
\text { (Group II) } \\
\text { Measurements (32) } \\
\text { Measurements (33) }\end{array}$ & \\
\hline 41 & & & $\begin{array}{l}\text { Shopping } \\
\text { Money }\end{array}$ \\
\hline $\begin{array}{l}43 \\
44\end{array}$ & & $\begin{array}{l}\text { Holidays } \\
\text { Politics }\end{array}$ & Superstition \\
\hline 45 & & $\begin{array}{l}\text { Education } \\
\text { Time } \\
\text { Space }\end{array}$ & $\begin{array}{l}\text { Drink } \\
\text { Literature }\end{array}$ \\
\hline $\begin{array}{l}46 \\
48\end{array}$ & & Religion & Sex roles \\
\hline 50 & Newspapers & American character & \\
\hline $\begin{array}{l}51 \\
53\end{array}$ & & $\begin{array}{l}\text { Manners } \\
\text { Superstition } \\
\text { Postage } \\
\text { Color }\end{array}$ & Famous places \\
\hline 54 & & $\begin{array}{l}\text { Sports } \\
\text { Newspapers }\end{array}$ & \\
\hline $\begin{array}{l}56 \\
57\end{array}$ & & & $\begin{array}{l}\text { Customs } \\
\text { Industry }\end{array}$ \\
\hline 58 & $\begin{array}{l}\text { Table seating } \\
\text { Manners }\end{array}$ & & $\begin{array}{l}\text { The family } \\
\text { Cleanliness }\end{array}$ \\
\hline $\begin{array}{l}59 \\
60 \\
\end{array}$ & Religion & History & Food \\
\hline 61 & & $\begin{array}{l}\text { Magazines } \\
\text { Temperature }\end{array}$ & Medicine \\
\hline 62 & & & Meals \\
\hline 63 & $\begin{array}{l}\text { Sports } \\
\text { Space } \\
\text { Money }\end{array}$ & & \\
\hline 64 & & $\begin{array}{r}\text { Literature } \\
\text { Money }\end{array}$ & Leisure \\
\hline 65 & $\begin{array}{l}\text { The family } \\
\text { Postage } \\
\text { The telephone }\end{array}$ & & \\
\hline $\begin{array}{l}66 \\
69\end{array}$ & & $\begin{array}{l}\text { The telephone } \\
\text { Shopping } \\
\text { Forms of address }\end{array}$ & \\
\hline 70 & Table setting & $\begin{array}{l}\text { States } \\
\text { Driving }\end{array}$ & \\
\hline
\end{tabular}


TABLE 3 (Continued)

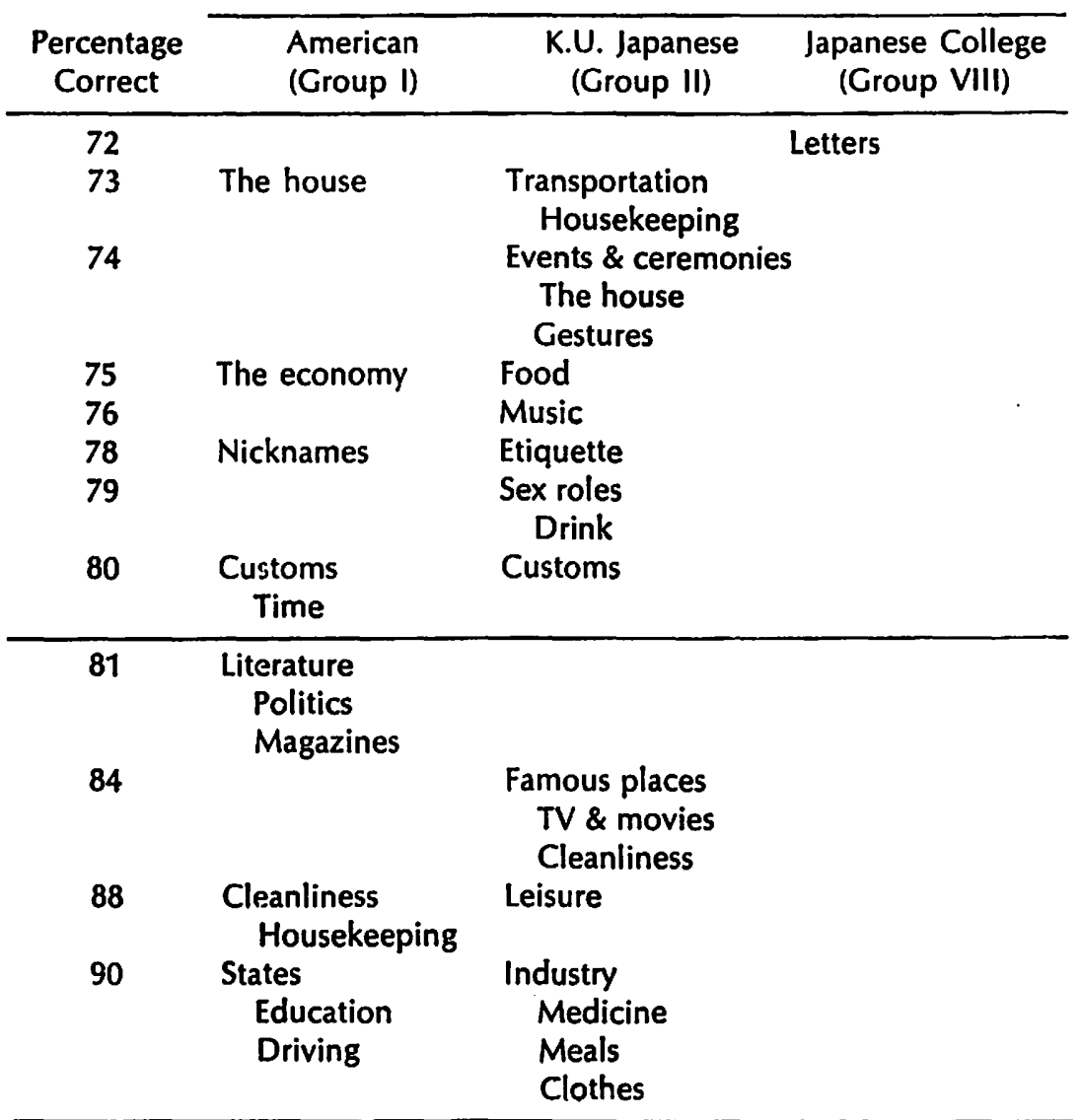

93

Famous places Letter

Holidays

American

character

Meals

Drink

Color

95 Transportation

Leisure

TV \& movies

Measurement (32)

Food

Forms of address

$98 \quad$ Music

Superstition

Sex roles 


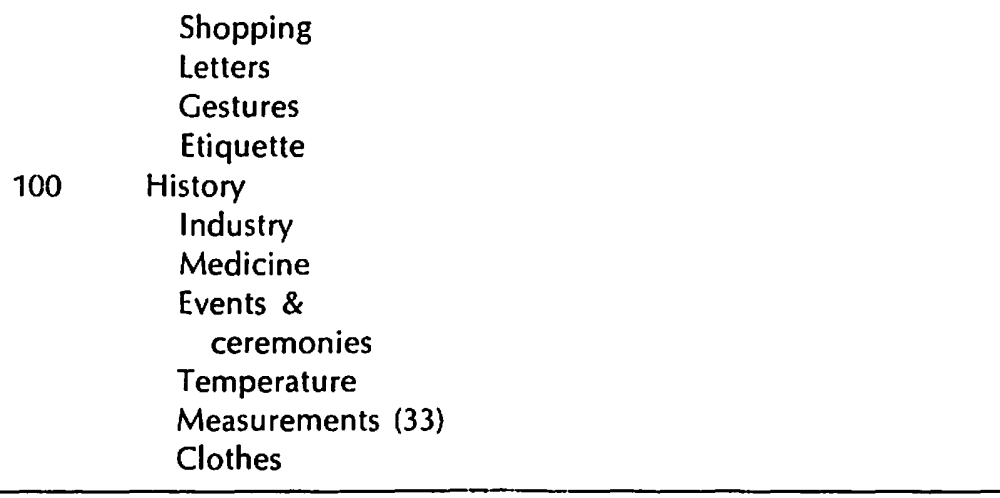

More than 50 percent of Americans answered every item correctly. More than 90 percent of Americans answered 26 items correctly. And every American answered 7 items correctly.

Only one item was answered correctly by more than 90 percent of the K.U. Japanese Students. Most items (45) were distributed almost evenly between 40 percent and 90 percent. On the other hand, fewer than 50 percent of the Japanese-college students answered forty items correctly. No item was answered correctly by as many as 80 percent of the Japanese-college students (the highest-71.9 percent). The percentage of correct answers on each item is shown in Table 3. Suprisingly, only between 50 and 60 percent of the Americans answered the items on religion, table seating, and manners correctly, and between 60 and 70 percent that on table setting. Seemingly this means young Americans are not too familiar with traditional religion or manners. Neither were they knowledgable on some practical information, such as postage and the telephone. They did not show so high a percentage on covert culture, such as space, and time, as I had predicted. On the other hand, they did well on questions of Culture with a big $C$ and daily life aspects of American culture. Thus most of the questions on the Test of American Culture seemed to be accurate.

The K.U. Japanese students were not so successful as the American students. They had the most difficulty with nicknames and had serious problems with measurements even though they encountered them almost every day. Since 45 items are well distributed, between 40 and 90 percent, few conclusions could be drawn. However, the results of the test did show that most aspects of covert culture except gestures-time, space, and color-were not well understood. Also, the students did not know about manners (table setting, table seating, and other aspects of manners) and practical information (postage, temperature, money, the telephone, and shopping). They understood some Culture with a big C (industry, famous places, music) and some daily life aspects of culture (letters, clothes, meals, medicine, leisure, TV and movies, etc.) relatively well but not sufficiently. Since they had been in the United States for a while, 
they seemed to have learned a good deal about the daily life part of culture but not about Culture with a big $\mathrm{C}$.

The Japanese-college students (VIII) were half as successful as the K.U. Japanese students on the test. They did not obtain a high percentage of correct answers on practical information items (transportation, postage, the telephone, temperature, measurements, driving, shopping, and money). They also had trouble with items related to manners (table setting, table seating, manners, forms of address, etiquette, and clothes). They had a predictable lower percentage on all the items on covert culture (time, color, gestures, and space). They knew very little even about Culture with a big $\mathrm{C}$. Fewer than 30 percent gave correct answers on 5 of the 13 items on Culture with a big $C$ (the economy, religion, history, sports, and American character), and fewer than 40 percent of another 4 items (states, education, music and politics). On only one such item, industry, did more than $\mathbf{5 1}$ percent answer correctly. It is obvious that if those students went to the United States, they would encounter many difficulties in daily life and would behave awkwardly in situations requiring certain expected manners.

I compared the ratios of difficulty of each of the test items for the K.U. Japanese students and the Japanese-college students as compared with that of the American students into frequency distribution and classified the fifty items according to those frequency distributions. The results are shown in Table 4.

TABLE 4

ITEM SUBJECTS IN ORDER OF RATIO OF DIFFICULTY OF

EACH ITEM THE JAPANESE STUDENTS COMPARED WITH THE AMERICAN STUDENTS

\begin{tabular}{|c|c|c|}
\hline \multirow[b]{2}{*}{ Ratio } & \multicolumn{2}{|c|}{ Students } \\
\hline & $\begin{array}{l}\text { K. U. Japanese } \\
\text { (Group II) }\end{array}$ & $\begin{array}{l}\text { Japanese College } \\
\text { (Group VIII) }\end{array}$ \\
\hline 0.17 & & TV \& movies \\
\hline 0.19 & & Transportation \\
\hline 0.21 & & Time \\
\hline 0.25 & & $\begin{array}{l}\text { History, newspapers, } \\
\text { the economy, events and } \\
\text { ceremonies }\end{array}$ \\
\hline 0.26 & & Magazines \\
\hline 0.28 & & American character \\
\hline 0.29 & & Color \\
\hline 0.30 & & Temperature, measurements(33) \\
\hline 0.31 & & $\begin{array}{l}\text { Postage, measurements }(32) \\
\text { table setting }\end{array}$ \\
\hline 0.33 & & The telephone \\
\hline 0.34 & & States, holidays, gestures, \\
\hline
\end{tabular}




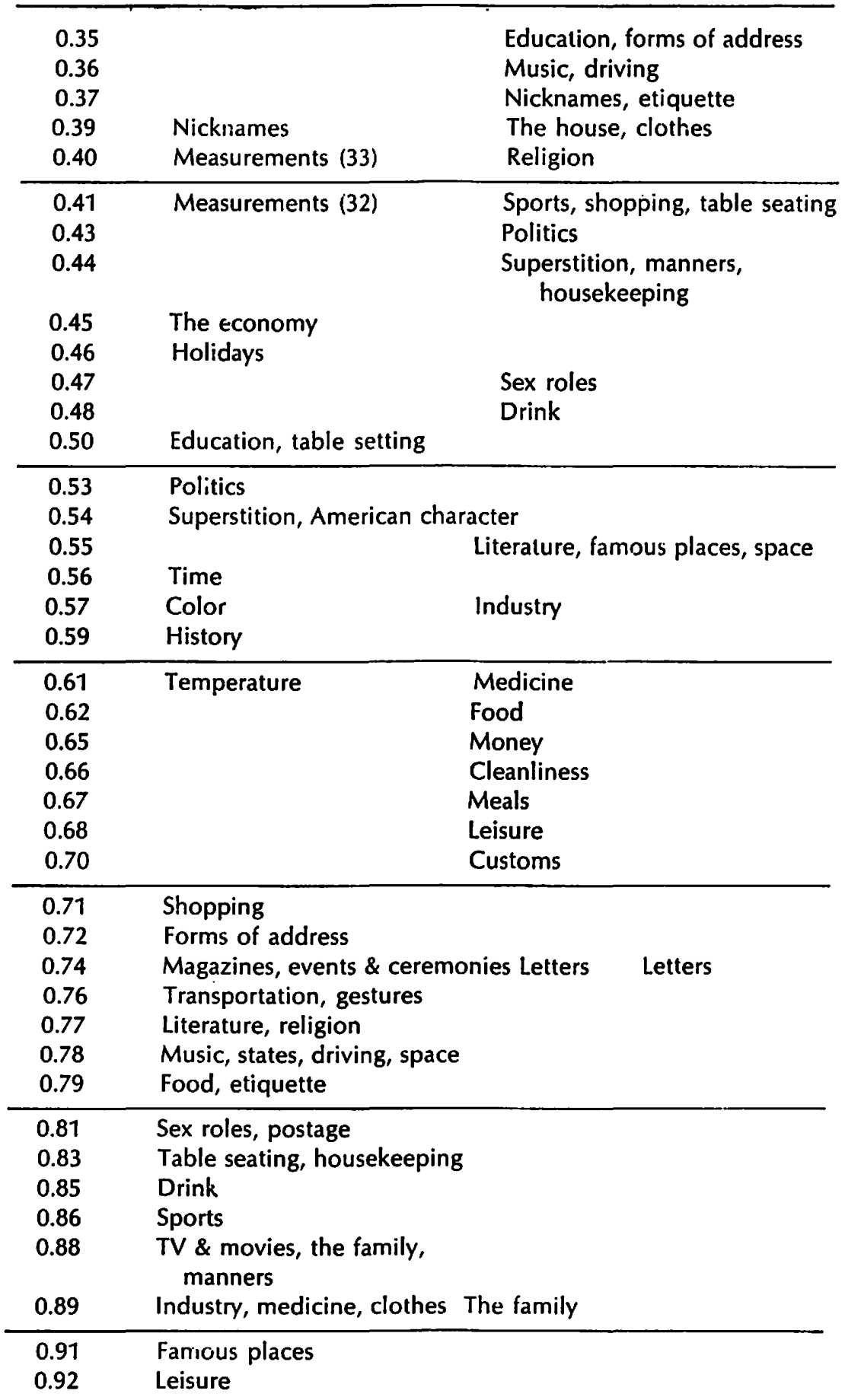




\begin{tabular}{lll}
\hline 0.95 & Letters \\
0.96 & Cleanliness & \\
0.97 & Meals \\
1.00 & Customs, newspapers \\
1.02 & The telephone, money, the house \\
\hline \multicolumn{3}{c}{ Students } \\
Ratio & K. U. Japanese & Japanese College \\
& (Group II) & (Group VIII)
\end{tabular}

The K.U. Japanese students answered 76 percent and the Japanese-college students $\mathbf{4 2}$ percent as many items correctly as did the American students on the Test of American Culture. More than 70 percent of the K.U. Japanese students answered as well as the American students on 36 items, and more than 80 percent on 22 items, and fewer than 50 percent on only 5 items. On the other hand, on only 2 items did more than 70 percent of the Japanese-college students answer as well as the Americans, and the ratio was less than 50 percent on 37 items. There is a great gap in the understanding of American culture but much less between the American students and the K.U. Japanese students.

The items on which K.U. Japanese students scored less than 50 percent related to measurements ( 2 items), nicknames, the economy, education and holidays. Most of these are very important in daily life. Even though they were students, they did not know much about American education. Next come items related to covert culture. On these areas, the students scored no higher than 80 percent on any item, with time and color offering the most serious problems. Some of the items in Culture with a big $C$ were problems too.

However, in comparison with the American students, the K.U. Japanese students did not have great difficulty with items on practical information and manners, except those concerning table setting and some of the daily life aspects of culture. Since they were living in the United States, they had learned a great deal about daily life culture in areas such as the telephone, money, postage, and driving, but not measurements and temperature. They obtained more than 80 percent on most items dealing with manners. Therefore, apart from a few items, the K.U. Japanese students achieved a fairly good percentage of correct answers on the Test of American Culture as compared with American students.

On the other hand, the Japanese-college students did not fare well on practical items as compared with American students, and they are very improtant matters when living and traveling in the United States. These items concerned transportation, measurements, temperature, postage, and the telephone. They also failed to obtain high ratios on items dealing with manners including table setting, forms of address, etiquette, and other aspects. Neither did they understand covert culture well. Time was the most difficult area, then color, and then 
gestures. These students did not understand the daily life aspect of culture well, nor did they know much about Culture with a big C.

The K.U. Japanese students did not know measurements and table setting facts well, even though those are very common matters in daily life. This means that just living in the United States is not enough to learn all the aspects of American culture, but it is useful for learning some parts. It is interesting to note the differences between the K.U. Japanese students and the Japanese-college students because these can indicate which of the areas of American culture that are unfamiliar in Japan can be learned about easily by just living in the United States and which cannot.

Comparisons between Japanese Students in the United States and in Japan

In order to make such differences clear, I compared Japanese-college students with K.U. Japanese students following the procedure previously used for comparison with the American students' scores. The results are shown on Table 5. Therefore, the lower the number in this table, the more easily are the relevant facts learned in the United States; the higher the number the more difficult it is to learn the facts.

TABLE 5

ITEM SUBJECTS IN ORDER OF RATIOS OF THE JAPANESE-COLLEGE STUDENTS COMPARED WITH THE K.U. JAPANESE STUDENTS

\begin{tabular}{ll}
\hline Ratio & Japanese College Students (Group VIII) \\
\hline 0.19 & TV \& movies \\
\hline 0.24 & Newspapers \\
0.25 & Transportation \\
\hline 0.32 & The telephone \\
0.36 & Magazines, events and ceremonies \\
0.37 & Time \\
0.38 & The house \\
0.39 & Postage \\
\hline 0.43 & History, clothes \\
0.44 & States \\
0.45 & Gestures \\
0.46 & Music, driving \\
0.47 & Sports, etiquette \\
0.49 & Temperature, forms of address \\
0.50 & Table seating, manners \\
\hline 0.51 & Religion, color \\
0.52 & American character \\
0.53 & Housekepeing \\
0.55 & The economy \\
\end{tabular}




\begin{tabular}{ll}
0.56 & Drink \\
0.58 & Sex roles \\
0.59 & Shopping \\
\hline 0.61 & Famous places, table setting \\
0.63 & Industry, money \\
0.67 & Medicine \\
0.69 & Meals, cleanliness \\
0.70 & Customs \\
\hline 0.71 & Literature, education, space \\
0.73 & Leisure \\
0.75 & Holidays, measurements (33) \\
0.77 & Measurements (32 \\
0.78 & Letters, food \\
\hline 0.82 & Politics, superstition \\
0.97 & Nicknames \\
1.00 & The family \\
\hline Ratio & Japanese College Students (Group VIII) \\
\hline
\end{tabular}

The Japanese-college students understood 57 percent of what the K.U. Japanese students did as a whole. The ratio was more than 80 percent on only 4 items. Thus, the K.U. Japanese students had learned a great deal about American culture in the United States.

To determine what the K.U. Japanese students had learned in the United States and what they had not, the percentage of correct answers on individual items were compared for K.U. and non-K.U. Japanese students. On daily life aspects of culture (TV and movies, newspapers, magazines, events and ceremonies, the house, etc.) and on practical information (transportation, the telephone, postage, etc.) and the Japanese-college students scored low comparatively, and percentages were also low on covert-culture items (time, gestures, and color). Some aspects of manners (etiquette, forms of address, table seating, and manners in general) were less well understood by the Japanese-college students. Thus, in the United States students can learn a good deal about superficial daily life aspects of American culture and some other areas of practical information as well as covert culture.

Both groups of Japanese students had trouble with measurements. There seemed to be a tendency not to learn something if it is not needed for daily life, such as facts concerning politics, superstition, leasure activities, and literature.

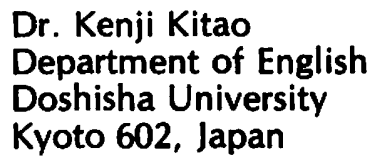




\section{Notes}

1. This study was conducted at the University of Kansas in 1976 for the writer's doctoral dissertation, and this paper was read at the thirteenth TESOL Convention.

Kenji Kitao, "The Teaching of American Culture in English Courses in Japan," Unpublished Doctoral Dissertation, (Lawrence, Kansas: The University of Kansas, 1977).

2. Homusho Nyugoku Kanrikyoku (The Immigration Bureau of the Ministry of Justice). "Showa 51 nen ni okeru Shutsu-Nyugoku-kanri no Gaikyo (The Number of People who Entered and Left Japan in 1976)," (Tokyo: Hemusho Nyugoku Kanrikyoku,, 1977).

3. Kenji Kitao, "The present Situation in the Teaching of American Culture in English Courses in Japan-Analysis of Junior and Senior High School English Textbooks in Japan-," Doshisha Studies in English, No. 21 (March, 1979), pp. 90-130.

4. Kenji Kitao, "A survey of the Teaching of American Culture with K.U. Japanese Students," Doshisha Studies in English, No. 19 (August, 1978), pp. 153-174.

Kenji Kitao, "English Education in Japan from the Perspective of Japanese Teen-age Students in the United States," Chubu English Education Society "Kiyo," No. 8 (March, 1979), pp. 67-80.

5. In order to make a culture test, I used the following books:

Henry Steele Commarger, Meet the U.U. .1., (New York: Institute of International Education, 1959).

Gladys G. Doty and Janet Ross, Language and Life in the U.S.A. 3rd ed. vol. II: Reading English, (New York: Harper \& Row, Publishers, 1973).

Barbara Teri Okada and Nancy Taeko Okada, Dos and Don'ts for The Japanese Businessman Abroad, (New York: Regents Publishing Company, Inc. 1973).

Ethel and Martin Tiersky, The U.S.A.: Customs and Institutions, (New York: Regents Publishing Company, Inc. 1970).

6. In order to make a culture test, I refered to the following previous studies.

John L. D. Clark, "Measurement Implications of Recent Trends in Foreign Language Teaching," in Foreign Language Education: Reappraisal: ACTEL Review of Foreign Language Education Vol. 4 ed. by Dale L. Lange and Charles J. James, (Skokie, Illinois: National Textbook Company, 1972), pp. 246-248.

Robert Lado, "How to Test Cross-Cultural Understanding," in Language Testing: The Construction and Use of Foreign Language Tests, (New York: McGraw-Hill Book Company, 1961), pp.275-289.

Genelle G. Morain, "Cultural Pluralism," in the Britanica Review of Foreign Language Education, Vol. 3 ed. by Dale L. Lange, Chicago: Encyclopedia Britannica, Inc. 1971), pp.59-95.

Howard L. Nostrand, "Empathy for a Second Culture: Motivations and Techniques," in Responding New Realities: ACTFL Review of Foreign Language Education, Vol. 5 ed. by Gilbert A. Jarvis, (Skokie, 
Illmois Textbook Company, 1974), pp. 295-297.

H. Ned Seely, "Field Notes on Cross-Cultural Testing," Language Learning, Vol. XVI, Nos 1 \& 2 (1966), pp. 77-85.

$H$. Ned Seelye, "Analysis and Teaching of the Cross-Cultural Context," in Foreign Language Education: An Overview: ACTFL Review of Foreign Language Education, Vol. 1 ed. by Emma M. Birkmaier, (Skokie, Illinois: National Textbook Company, 1974), pp. 37-81.

J.A. Upshur, "Cross-Cultural Testing: What to Test," Language Learning, Vol. XVI, Nos 3 \& 4 (1966), pp. 183-196.

Fathi S. Yousef, "Cross-Cultural Testing: An aspect of the

Resistance Reaction," Language Learning, Vol. XVIII, Nos. 3 \& 4 December, 1968, pp. 227-234.

I explained the procedure of making a culture test in the following papers.

Kenji Kitao, "Beikoku Bunka Tesuto Sakusei no tame no Koso

Basic Concept in Constructing Tests of American Cultural Awareness)," Nihon Eigo Kyoiku Gakkai Kansai Shibu "Kenyu Shuroku," (The English Language Education Society of Japan, Kansai Chapter "Collected Research Papers,"], No. 2 (March, 1979), pp. 38-42.

Kenji Kitao, "Beikoku Bunka Tesuto-Sono Sakusei Hoho (A Test of American Cultural Awareness-Construction Procedures), Eigo Kyoiku (The English Teachers' Magazine), Vol. XXVIII, No. 5 (August, 1979), pp. 22-24 \& p. 30.

7. I refered the following books.

Walter Powell Allen, "A Checklist for American Culture," in Selecting Reading Materials for Foreign Students, (Washington, D.C.: Washington Publishers, 1955), pp. 17-29.

Nelson Brooks, Language and Language Learning: Theory and Practice, (New York: Harcourt, Brace \& World, 1964).

Commager, op. cit.

Doty and Ross, op. cit.

Okadas, op. cit.

Tiersky, op. cit. 


\section{APPENDIX}

This is the test to measure how much you understand or know American culture. Here are 100 questions. From 1-50 just choose one answer which is strongly associated or appropriate to the question word. From 51-100, just select one answer which fits the blank. There is only one correct answer to any question. If you do not find the answer, just leave it.

Please do not write anything on the question sheet. Just circle the correct answer on the answer sheet as the following example shows. EXAMPLE, the largest state: (a) Alaska (b) Texas (c) New York (d) Kansas

Alaska is the largest state in the U.S., so circle 1 on the answer sheet.

1. The Old Man and the Sea: (a) Mark Twain (b) Robert Frost (c) Eugene O'Neil (d) Ernest Hemingway

2. jazz: (a) New York (b) Chicago (c) New Orleans (d) Los Angeles

3. the Declaration of Independence: (a) George Washington (b) Thomas Jefferson (c) Benjamin Franklin (d) Abraham Lincoln

4. Detroit: (a) automobiles (b) steel (c) aircraft (d) oil

5. governor: (a) state (b) city (c) county (d) federal

6. Hollywood: (a) New York (b) Washington, D.C. (c) Los Angeles (d) San Francisco

7. New England: (a) New York (b) Vermont (c) Michigan (d) Kansas

8. Amtrack: (a) train (b) bus (c) subway (d) airplane

9. a black cat: (a) happiness (b) many children (c) bad luck (d) wealth

10. National League: (a) Royals (b) Yankees (c) Dodgers (d) Red Socks

11. one of the biggest religious denominations: (a) Nazarene (b) Congregational (c) Christian Science (d) Baptist

12. a nation-wide daily newspaper: (a) New York Times (b) Washington Post (c) Time (d) none

13. a weekly magazine: (a) Reader's Digest (b) National Geographic (c) Time (d) Wall Street Journal

14. minimum wage per hour: (a) $\$ 1.60$ (b) $\$ 2.00$ (c) $\$ 2.20$ (d) not specified

15. compulsory education: (a) for 6 years (b) for 9 years (c) until 16 years old (d) until 18 years old

16. the most common pasttime at home: (a) playing cards (b) watching TV (c) Knitting (d) reading

17. a local TV station: (a) KCMO (b) CBS (c) ABC (d) NBC

18. headache: (a) Pepto Bismal (b) aspirin (c) cough syrup (d) Vick's Vapa-Rub

19. teachers in elementary schools: (a) mostly women (b) mostly men (c) half women (d) only men

20. divorce rate: (a) $10 \%$ (b) $20 \%$ (c) $40 \%$ (d) $60 \%$ 
21. speed limit on major highways: (a) $40 \mathrm{mph}$ (b) $55 \mathrm{mph}$ (c) $65 \mathrm{mph}$ (d) $75 \mathrm{mph}$

22. holiday in October: (a) Lincoln's Birthday (b) Labor Day (c) Halloween (d) Easter

23. Fourth of July: (a) minister (b) turkey and dressing (c) fireworks (d) colored eggs

24. common gifts: (a) birthday (b) New York's Day (c) funeral (d) 4th of July

25. not a common American characteristic: (a) social mobility (b) competition (c) materialism (d) superstition

26. average body temperature: (a) $95.5 F($ b) $98.6 F(c) 100.2 F(d)$ 102.3F

27. sales tax: (a) $3 \%$ (b) $5 \%$ (c) only for luxury items (d) depends on each state's policy

28. cheapest postal rates: (a) books (b) printed matter (c) Parcel (d) first class

29. cheapest telephone rates: (a) person-to-person (b) collect (c) station-to-station (d) person-to-person collect

30. dime: (a) 1 cent (b) 5 cents (c) 10 cents (d) 25 cents

31. last expression in a letter: (a) Thank You. (b) Goodbye. (c) Sincerely yours, (d) I am looking forward to hearing from you soon.

32. 1 pint: (a) two cups (b) two quarts (c) half gallon (d) half cup

33. one pound: (a) $8 \mathrm{oz}$ (b) $10 \mathrm{oz}$. (c) $12 \mathrm{oz}$. (d) $16 \mathrm{oz}$.

34. Elizabeth: (a) Ellen (b) Betty (c) Kathy (d) Emillie

35. dessert: (a) roll (b) banana bread (c) muffin (d) vegetable salad

36. main dish: (a) salad (b) soup (c) meatloaf (d) vegetables

37. napkin (table setting): (a) left of the plate (b) right of the plate (c) above the plate (d) under the plate

38. right side of a host: (a) gentleman of honor (b) second most important gentleman (c) lady of honor (d) second most important lady

39. introduction: (a) men to women (b) women to men (c) old people to young people (d) no rules

40. inappropriate etiquette: (a) holding a door for a lady (b) carrying food to the mouth with a knife (c) telling compliments (d) helping ladies with their baggage

41. liquor: (a) scotch (b) coke (c) beer (d) coffee

42. for women in general: (a) Mrs. (b) Miss (c) Ms. (d) Dr.

43. average size of houses: (a) 7 rooms (b) 3 bedrooms (c) 2 garages (d) 3 bathrooms

44. taking shower: (a) everyday (b) every other day (c) once a week (d) twice a day

45. housekeeping: (a) maid (b) servant (c) wife (d) husband

46. for only women: (a) pantsuits (b) jeans (c) suits (d) bathrobe

47. to shrug shoulders: (a) I'm sorry. (b) I beg your pardon. (c) I don't know. (d) important point 
48. average refrigerator: (a) 3 feet high (b) 4 feet high (c) 6 feet high (d) 8 feet high

49. office hours: (a) 8 a.m. -5 p.m. (b) 9 a.m. $-5: 30$ p.m. (c) $8: 30$ a.m. $-5: 00$ p.m. (d) 9 a.m. -6 p.m.

50. depression (color): (a) yellow (b) white (c) red (d) blue

51. Light in August was written by-.(a) Hemingway (b) Faulker (c) Poe (d) Steinbeck

52. - is famous for country music. (a) St. Louis (b) Nashville (c) Denver (d) Kansas

53. The Gettysberg Address was given by-. (a) Abraham Lincoln (b) Patrick Henry (c) Daniel Boone (d) Martin Luther King, Jr.

54. The main industry zone of the U.S. is in the - (a) northwest (b) southwest (c) northeast (d) southeast

55. There are-senators in the Congress. (a) 10 (b) 50 (c) 100 (d) 155

56. The Lincoln Memorial is located in-. (a) New York (b) Washington. D.C. (c) Chicago (d) Springfield

57. - is one of the states in the South. (a) West Virginia(b) Mississippi (c) Arizona (d) Minnesota

58. One of the major-services is Greyhound. (a) bus (b) train (c) subway (d) airplane

59. If you break a mirror, you will be in bad luck for-years. (a) 1 (b) 3 (c) 5 (d) 7

60. The traditional football season is in the - (a) spring (b) summer (c) fall (d) winter

61. Jewish people usually go to the synagogue on-evening, (a) Sunday (b) Monday (c) Friday (d) Saturday

62. American newspapers carry little-. (a) local news (b) advertisements (c) sport news (d) international news

63. - is issued monthly. (a) New Yorker (b) U.S. News and World Report (c) TV Guide (d) Seventeen

64. The average annual income is - (a) $\$ 5,000$ (b) $\$ 10,000$ (c) $\$ 15,000$ (d) $\$ 20,000$

65. "Senior" in high school refers to the -th grade. (a) 10 (b) 11 (c) 12 (d) 1366.

66. Most people take vacations in the (a) winter (b) spring (c) summer (d) fall

67. Only people above 18 years old can see--rated movies. (a) G (b) PG (c) R (d) X

68. When you need medicine, you buy it from the - - (a) hospital (b) doctor (c) drug store (d) dime store

69. According to the law, women are to be paid-men. (a) more than (b) less than (c) the same as (d) not specified

70. Average sized families have-people. (a) 2 (b) 3 (c) 5 (d) 7

71. In most states people can start driving when they are-years old. (a) 15 (b) 16 (c) 18 (d) 20

72. People bring flowers to graves on-. (a) Veteran's Day (b) Fourth of July (c) Thanksgiving (d) Memorial Day

73. Caps and gowns are used for - (a) weddings (b) funerals (c) 
engagements (d) graduations

74. If you are invited to a dinner, you-to the hostess as a custom. (a) bring a rose (b) bring the dessert (c) send a thank-you note afterwards (d) don't do anything special

75. The American dream is the belief that any individual can achieve wealth and fame through - (a) birth (b) privilege (c) hard work and honesty (d) good luck

76. Water begins to freeze at $-F$. (a) 0 (b) 10 (c) 21 (d) 32

77. The biggest sale in the year is-. (a) after Xmas (b) in summer (c) before Easter (d) on Washington's birthday

78. Regular first class mail costs-cents each. (a) 8 (b) 10 (c) 13 (d) 15

79. If you call somebody with-rate, it is cheapest. (a) day (b) evening (c) night (d) weekend

80. Average Americans seldom carry more than $\$$-cash. (a) 10 (b) 50 (c) 100 (d) 200

81. The normal salutation of a letter is-. (a) Dear-: (b) Hello! (c) How are you? (d) season's greeting

82. Two feet equals -inches. (a) 12 (b) 18 (c) 24 (d) 30

83. One yard equals - feet. (a) 3 (b) 5 (c) 10 (d) 15

84. -is a nickname for Margaret. (a) Mary (b) Marian (c) Peggy (d) Becky

85. Typical lunch is - (a) pancake (b) cereal (c) sandwich (d) steak

86. Dinner is usually eaten around-o'clock on weekends. (a) 12 (b) 4 (c) 6 (d) 8

87. Water glasses are set-. (a) to the right of the knife (b) at the tip of the knife (c) on the plate (d) to the left of the fork

88. A hostess sits across from - (a) the host (b) the fireplace (c) a cabinet (d) the main guest

89. Poor manners are that-. (a) you eat silently (b) you use a fork with your right hand (c) you leave right after you finish your eating (d) you keep a napkin on your lap while eating

90. It is not appropriate to- . (a) ask a lady her age (b) stand up when you are introduced (c) send a season-greeting card (d) take coats of visitors

91. Americans often drink - with meals. (a) pop (b) cocktail (c) gin (d) whisky

92. The politest way to address a doctor is to call-. (a) first name (b) Mr. (first \& surname) (c) Dr. (first name) (d) Dr. (first \& surname)

93. Middle class people often live in (a) the heart of a big city (b) downtown (c) the country (d) the suburbs

94. Many American women put on-when they go out. (a) perfume (b) hair cream (c) hand cream (d) soap

95. Major housekeeping is - (a) once a day (b) every other day (c) weekly (d) biweekly

96. - are formal clothes. (a) summer dress (b) short skirts (c) sport coats (d) tuxedos

97. Crossing fingers means-. (a) friendship (b) love (c) good 
luck (d) money

98. Common speaking distance is-. (a) $1 \mathrm{ft}$ (b) $1.5 \mathrm{ft}$ (c) $2 \mathrm{ft}$ (d) $3 \mathrm{ft}$

99. If you have an appointment at 3 o'clock, you should be there at-. (a) 2:45 (b) 3 o'clock (c) 3:15 (d) 3:30

100. - connotates young, inexperience and immature. (a) brown (b) orange (c) pink (d) green

\section{This publication is available in microform.}

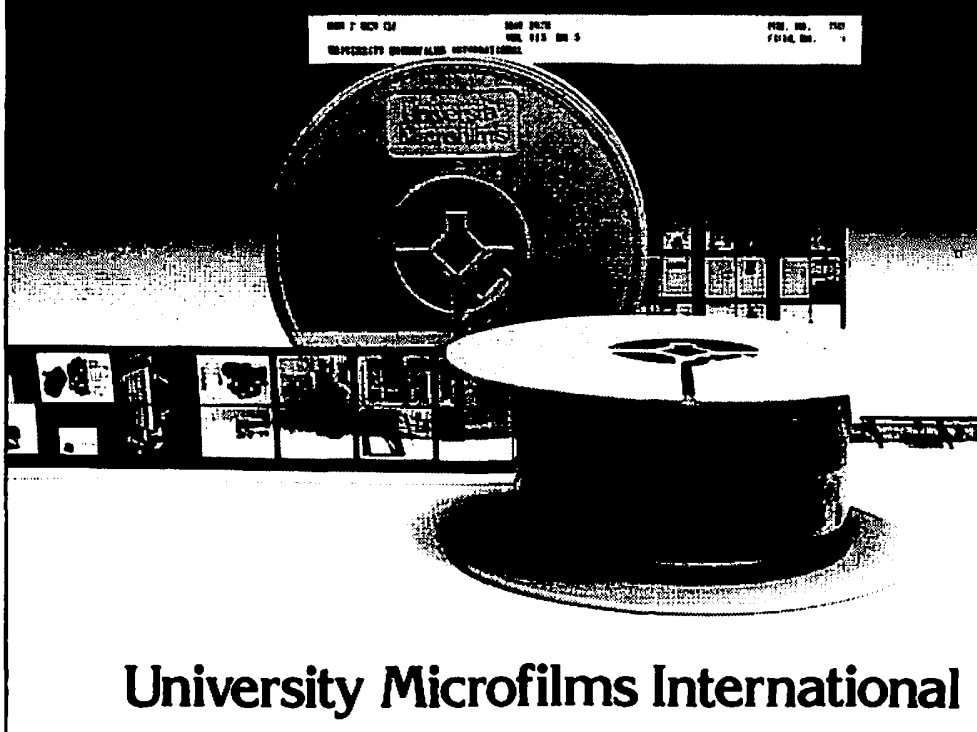

Please send additional information

Name

Institution

Street

City

State Zip

300 North Zeeb Road Dept. P.R.

Ann Arbor, Mi. 48106 U.S.A.
30-32 Mortimer Street

Dept. P.R.

London W1N 7RA

England 